\title{
REDAKTORIAUS ŽODIS / EDITORIAL
}

Globalizacijos procesai, skatinami sparčiai tobulejančiu ir neitikètinas galimybes atveriančiu technologiju, artina tautas, glūdina kultūrinius skirtumus, niveliuoja išskirtinumus. Darnioji arba tvarioji plètra, kaip atsvara civilizacijos padariniu keliamai grèsmei ivairiose gyvenimo srityse, kurios suinteresuotos, kad „dabarties poreikius atitinkanti plètra nekeltu pavojaus ateities kartoms tenkinti savuosius poreikius" (Brundland'o ataskaita, 1987), tampa prioritetine sritimi ne tik aplinkosaugoje, ekonomikoje, socialinejje-politinèje srityje, bet ir kultūros sferoje. Mūsu stiprybè - ivairovèje. In varietate concordia arba "unity in diversity" - šis žodinis Europos simbolis, oficialus Europos Sajungos devizas atspindi sieki darniai sugyventi, gerbti ir saugoti ne tik biologinę, bet ir kultūrinę ivairovę - kiekvienos šalies tapatuma, ji palaikančią kalbą, tradicijas, tautos dvasinius turtus.

Visuomenès daugiakalbystè ir individuali daugiakalbystè - prioritetinès darniosios plètros kryptys kultūros srityje. Skirdami deramą dèmesi kiekvienai kalbai, išlaikysime savo kultūrini išskirtinuma; plèsdami galimybes mokytis, studijuoti, tirti kalbas, praturtinsime savo kultūrini kraštovaizdi, sudarysime salygas augti naujai kartai, kuri gerbia savo paveldą ir geba perteikti šalies savasti pasaulio tautoms ju kalba, be vertejo, iš širdies i širdi.

Vytauto Didžiojo universitete dèmesys daugiakalbès kompetencijos igijimui ir išlaikymui, kaimyniniu šaliu ir rečiau vartojamu kalbu mokymuisi, užsienio kalbu mokymo pasiūlai visada buvo išskirtinis nuo pat universiteto atkūrimo $1989 \mathrm{~m}$. Todèl neatsitiktinai Užsienio kalbu instituto mokslo klasteryje "Daugiakalbystès kompetencijos tobulinimo tyrimai" buvo subrandinta ideja apie naujo periodinio leidinio - mokslo žurnalo „Darnioji daugiakalbystè" - leidima. Gavus bendraminčiu kolegu iš 11 šaliu pritarima, darbai isibègejjo ir naujas žurnalo numeris teikiamas jūsu dèmesiui.

Pirmajame žurnalo skyriuje - „Visuomenè. Identitetas. Kalbos" - nagrinèjama skirtinga lietuviu ir latviu tautinès savimonès raida bei jos skirtumu priežastys, kurias lèmé susiklosčiusi nevienoda luominè abieju tautu struktūra (A. Butkus, V. Butkienè), aptariama vieningos visai Europai kalbos paieška, kaip išeiti siūlant atnaujintą šiuolaikišką lotynu kalbą (A. Bernini), nagrinėjama daugiakalbystè Lietuvos Didžiojoje Kunigaikštysteje, aptariant ištakas bei sąsajas su Lietuvos visuomenès vystymusi, politiniu, kultūriniu savitumu, lingvistine jvairove ir etninio identiteto formavimusi (S. Lūžys), nagrinèjama bendros europinės tapatybès problema istoriniu ir sisteminiu aspektais (M. Lonz). Antrajame skyriuje - „Daugiakalbès 
kompetencijos tobulinimas aukštojoje mokykloje" - nagrinejama Latvijos ir Lietuvos patirtis, analizuojamos prancūzu (J. Durandin), ispany (R. Sabaliauskienè), latviu (Dz. Šulce), anglu (V. Tuomaitė; V. Daugèlaitè, A. Jankauskaitè, V. Sabaliauskienè) kalbu kaip bendrosios užsienio kalbos mokymo(si) problemos aukštajame moksle. Trečiajame skyriuje - "Kalbos didaktikos problemos" - analizuojamas IKT taikymas integruojant kalbos ir dalyko mokymą (V. Bijeikienè, D. Pundziuvienè, L. D. Zutkienè) bei pristatomi akademinio klausymo problemu srities tyrimai (I. Ozola; A. Sabaliauskienè).

Žurnalo tikslas - pažvelgti i daugiakalbystès fenomeną jvairiais aspektais iš kalbu politikos, didaktikos, mokymosi ir isisavinimo, taikomosios kalbotyros, svetimu kalbu mokymo, sociolingvistikos, psicholingvistikos, neurolingvistikos, edukologijos, istorijos, filosofijos, literatūros, psichologijos ir kt. mokslo krypčiu bei šaku perspektyvu. Skatindami darniaja daugiakalbystę ir daugiakultūriškuma, kviečiame pristatyti savo tyrimus ivairiomis kalbomis, pateikiant išsamias santraukas lietuviu ir anglu kalbomis.

Nemira Mačianskienè

Vyriausioji redaktorè

The processes of globalization, enhanced by rapidly advancing technologies which open incredible opportunities, bring nations closer together, level cultural differences and peculiarities. The concept of sustainable development which emerged as a counterbalance to the threat posed by civilization in various life areas, concerned with the "development that meets the needs of the present without compromising the ability of future generations to meet their own needs" (Brundland Report, 1987), has become a priority area not only in ecology, economics, social-political area, but in cultural sphere as well. Our strength is in our diversity. In varietate concordia or "unity in diversity" - this symbol of Europe, the official motto of the European Union, reflects the ambition to live in harmony, respecting and protecting not only biological but also cultural diversity, i.e. the identity of every nation, its languages, traditions, and spiritual wealth of the country.

Societal multilingualism and individual multilingualism (plurilingualism) are priority fields in the cultural area of sustainable development. Devoting appropriate attention to every language we can preserve our cultural exceptionality; widening opportunities for language learning, study and research we can enrich our cultural landscape and create opportunities for the young generation to grow cherishing their cultural heritage and being able to present their identity and richness to the nations of the world in their language without mediators, from heart to heart.

Since its reestablishment in 1989, Vytautas Magnus University has been exceptional in its attitude to the importance of plurilingual competence development 
and its sustainability, in offering opportunities for the students to learn foreign languages including those of neighbouring countries and less widely taught languages, in broadening the range of languages on offer for all. Consequently, the idea to share the research in the scientific journal published by the cluster of the Institute of Foreign Languages "Research in Plurilingual Competence Development" has not come about by accident. Having obtained the approval from congenial colleagues and partners from 11 foreign countries, the work gained momentum and here we present the first edition of the journal to your attention.

The first chapter of the journal - Society. Identity. Languages - presents the research on the distinct development of Lithuanian and Latvian national selfawareness due to diverse historical experience, i.e. different estate structure of both nations (A. Butkus, V. Butkienè), the search for a common European language, recommending the use of a modern and updated Latin as a solution to the problem (A. Bernini), investigations on multilingualism in the Grand Duchy of Lithuania (S. Lūžys) and the analysis of the issue of a common European identity (M. Lonz). The second chapter - Development of Plurilingual Competence in Higher Education - presents research of Latvian and Lithuanian experience - issues in teaching and learning French (J. Durandin), Spanish (R. Sabaliauskienè), Latvian (Dz. Šulce), English (V. Tuomaitè; V. Daugèlaitè, A. Jankauskaitè, V. Sabaliauskienè) as foreign languages in higher education. Chapter three - Issues in Language Didactics - analyses the application of ICT in integrating content and language teaching and learning (V. Bijeikiené, D. Pundziuvienè, L. D. Zutkienè) and presents research in academic listening didactics (I. Ozola; A. Sabaliauskienè).

The aim of the scientific journal "Sustainable Multilingualism" is to focus on the phenomenon of multilingualism from perspectives of various fields - language policy, didactics, learning and acquisition, applied linguistics, foreign language teaching, sociolinguistics, psycholinguistics, neurolinguistics, education science, history, philosophy, psychology, literature and other fields and branches of science. Fostering sustainable multilingualism and multiculturalism, we invite you to share your research in various languages, presenting comprehensive summaries in Lithuanian and English.

Nemira Mačianskienè Editor-in-Chief 